\title{
PCR-Technique Reveal the Potential of Cheiracanthium isiacum as a Phyllocnistis citrella Predator
}

\author{
Zaher*, M. A.; M. F. Hassan*; \\ Gihan M. E. Sallam** and Doaa M. A. Abdel Ghani ** \\ *Dept. of Zoology and Agric. Nematology, Fac. of Agric., Cairo Univ., Giza, Egypt. \\ ***Plant Protec. Res. Institute, Agric. Res. Cent. Dokki, Giza, Egypt, Doaamahmoud18@gmail.com.
}

\begin{abstract}
The experiment was conducted in a small greenhouse of citrus plants to know the population dynamic and the relationship between the Eutichurid spider Cheiracanthium isiacum and the occasional pest Phyllocnistis citrella. There was a statistically significant difference within three times in dominance of $P$. citrella. Results show that it is possible to detect $P$. citrella DNA in $C$. isiacum by using PCR technique and confirm the greenhouse experiment that there is a specific relationship between it. Cheiracanthium isiacum may be important in suppressing this pest population below economic threshold
\end{abstract}

Key words: Cheiracanthium isiacum, Phyllocnistis citrella, Predator-prey interaction, Gut content analysis.

\section{INTRODUCTION}

Spiders, as generalist predators feeding on alternative prey. High spider-pest ratios early in the season may reduce the pest increase rate sufficiently to enable later-arriving specialist natural enemies to suppress the pest population below the economic threshold (Wheeler, 1973; Zhang, 1992).

The target pest citrus leafminer (CLM) Phyllocnistis citrella attacks all citrus varieties; larvae infest the young flushing foliage producing a snake-like 'mine' as they feed. This damage causes the attacked leaves to twist and curl. P. citrella is an important pest in citrus nurseries and top-grafted trees (Diez et al., 2006). According to Carroll (1980) various species of sac spiders (Cheiracanthium sp., Hibana sp., and Trachelas sp.) contributed to the control of lepidopterous pests, mites, and thrips in California citrus orchards. In homestead Florida, survey results also showed that this group of spiders was a dominant component of the community. The predator Chiracanthium inclusum detects the prey by sensing vibrations of the substrate induced by the concealed prey. Movement of $P$. citrella larvae and prepupae appear to create vibrations of the leaf substrate, which then serve as cues for the spiders to locate them. It was found to start feeding on P. citrella larvae during the second instar stage. Consumption increased as they developed to later instars. Maximum consumption was recorded at the $4^{\text {th }}$ instar. Results obtained from this study provided useful data to better understand the role of it in the overall management of P. citrella. (Amalin, et al. 2001).

The most mathematical treatments are limited to single species predatory effects on one and sometimes two prey populations, because data on multispecies predator-prey systems are generally lacking and modeling of such systems is very complex. Essential to single species predator-prey control is a stable interaction of predator and prey population. Stability is achieved by density-dependent responses of predator to the prey.

One way to obtain very specific consumption data at the species level is to collect predators in their natural environment, preserve them and search for remains of ingested prey in their gut-contents (Sunderland, 1988; Symondson, 2002). PCR has turned out to be an advantageous method for arthropod gut content analysis as it is highly sensitive and because application requires skills and equipment that are common in many labs (Greenstone \& Hunt, 1993; Greenstone \& Shufran, 2003).

\section{MATERIALS AND METHODS}

\section{a. Greenhouse experiment}

Twenty seedlings of citrus planted in a small greenhouse covered with theran to know the population dynamics and the relationship between the spider Cheiracanthium isiacum and the occasional pest Phyllocnistis citrella.

\section{b. Gut content analysis}

Gut analysis of field-collected spiders is least disruptive and the most efficient means to acquire data on predation (Stuart and Greenstone, 1990)

\section{Collection of predators and prey}

Adult and juvenile of Cheiracanthium isiacum spiders. Pure larvae of Phyllocnestis citrella were collected as positive control at random from citrus trees in a greenhouse at Giza governorate. Spiders were collected in two months, September and October. Predators and target prey were frozen immediately after collection in individual tubes to reduce the breakdown of gut-contents, and starved Cheiracanthium isiacum as negative control. 


\section{Specific primer design of the target prey}

Primers were designed for Phyllocnistis citrella as a target prey from specific gene AYK_MJ_C17 cytochrome oxidase subunit 1 (COI) gene. The DNA fragment was amplified using the forward primer and reverse primer.

\section{DNA extraction}

The procedure for DNA extraction was kit-based using QIAamp Mini spin column (QIAGEN Cat. No. 51304).

\section{Polymerase Chain Reaction (PCR) reactions}

For DNA amplification, a mixture reaction was prepared for each sample using the primers $(1 \mu 1$ for each of the forward and reverse primers) by adding PCR Master Mix $(2 x, 12.5 \mu 1)$, template DNA $(2 \mu 1)$, water, nuclease-free $(8.5 \mu \mathrm{l})$ then bring the final volume to $25 \mu 1$. PCR cycling on the thermocycler was as follows: $95^{\circ} \mathrm{C}, 5 \mathrm{~min}$.; $95^{\circ} \mathrm{C}, 58^{\circ} \mathrm{C}, 72^{\circ} \mathrm{C}$, $30 \mathrm{~s}$. for 40 cycles; and the final extension $72^{\circ} \mathrm{C}$.

\section{Visualization and scoring of PCR products}

All PCR products were separated by agarose gel electrophoresis. The gels were stained with ethidium bromide and the PCR products subsequently visualized under UV light. A sample was scored as positive when a band of approximately $153 \mathrm{bp}$ ( $P$. citrella amplicon $=$ PCR products $)$ appeared on the gel.

\section{c. Statistical analysis by SPSS version 21}

All data were analysed using repeated measures ANOVA, a statistical technique for testing for differences between the means of three time points and use the Pearson correlation coefficient to examine the strength and direction of the linear relationship between two continuous variables.

\section{RESULTS AND DISCUSSION}

\section{a. Population dynamic}

The Eutichurid spider Cheiracanthium isiacum does not capture prey by means of webs, but instead run down and capture their food. $C$. isiacum is the dominant species in citrus seedling in greenhouse. It is one of active hunting spider which active at night (Nocturnal spider) and by day it makes a retreat to stay in it so, the samples of this spider taken from the foliage of citrus and the target pest which also dominant is Phyllocnistis citrella (Fig. 1). This pest is highly exposed to attack by Cheiracanthium isiacum (Fig. 2).

In early June, the numbers of $C$. isiacum increased when $P$. citrella increased and in the middle of month when the number of $P$. citrella decreased the numbers of $C$. isiacum decreased and in the end of month the reverse was also true. There was statistically significant difference within three times in dominance of $P$. citrella, $\mathrm{F}(2,8)=14.82, \mathrm{p}<0.002$ (Fig, 3).

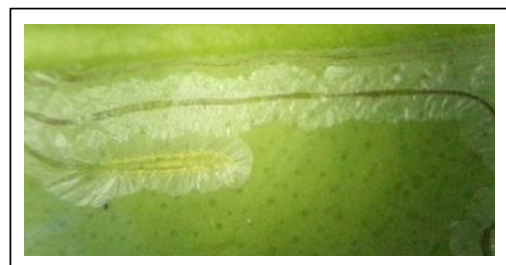

Fig. (1): Larvae of Phyllocnestis citrella.

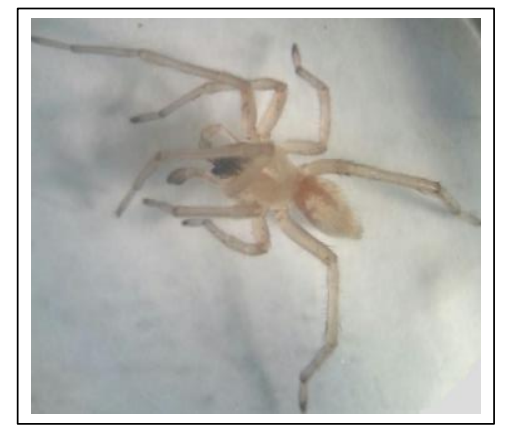

Fig. (2): Adult of Cheiracanthium isiacum.

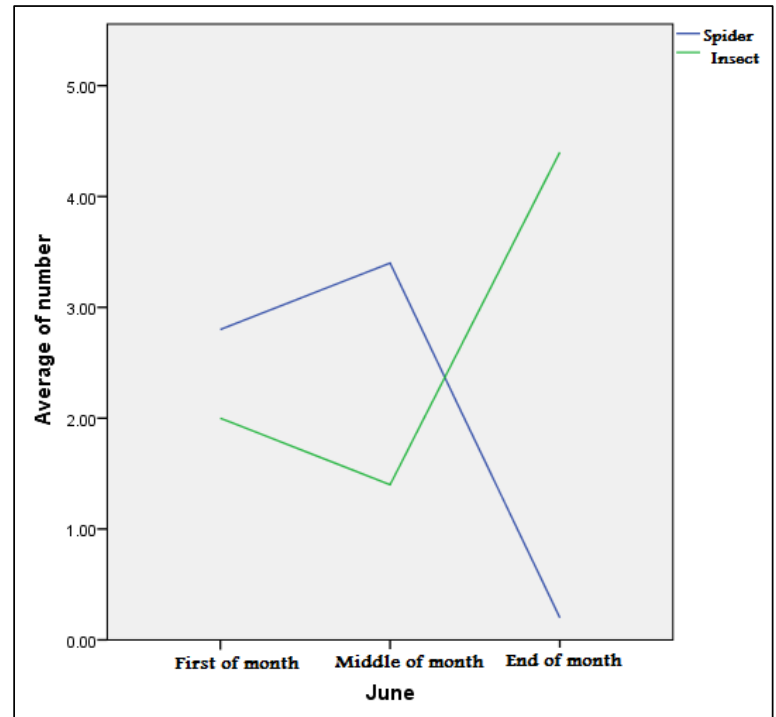

Fig. (3): Relationship between $C$. isiacum and $P$. citrella within three times in the month.

The correlation coefficient is -.787. This indicated a strong linear relationship between spider (Cheiracanthium isiacum) and leafminer (Phyllocnistis citrella). $\mathrm{N}=15, \mathrm{p}=0.000, \mathrm{R}$ Square $=62 \%$. Regression model predicts the dependent variable significantly well, $\hat{Y}=4.36-0.827(\mathrm{X})$ the $\mathrm{b}$ value of 0.827 indicated that for each additional of independent variable (spider) can expect to decrease the number of dependent variable (pest) by about 0.83 . The range of presence of spider $1: 4$ in infested trees of citrus and nothing in non infested trees.

\section{b. PCR assay}

Predators were collected in the morning from citrus trees in greenhouse. To minimize degradation 
of DNA in their stomach contents, predators were frozen immediately after capture. DNA was extracted from spiders and specific $P$. citrella DNA fragment of a defined length, was amplified by PCR. The PCR products were separated by agarose gel electrophoresis and the gels were stained with a dye that binds to DNA and irradiates under UV-light. If the visualized PCR products (which appear as bright bands) were of expected length (153 bp) the samples were scored as positive and it was concluded that those predators had consumed $P$. citrella. If no bands appeared on this length of the gel, samples were scored as negative. Primers were designed of target prey Phyllocnistis citrella from specific gene YK_MJ_C17 cytochrome oxidase subunit 1 (COI) gene. The DNA fragment was amplified using the Forward primer TCCTGATATAGCTTTCCCACGA and Reverse primer CCACCGTGGGCAATATTAGA. The primers are short DNA fragments with a defined sequence complementary to the target DNA that is to be detected and amplified. These serve as an extension point for the DNA polymerase to build on.

Our results show that it is possible to detect $P$. citrella DNA in $C$. isiacum by using PCR technique and confirm the greenhouse experiment that there is specific relationship between them (Fig.4).

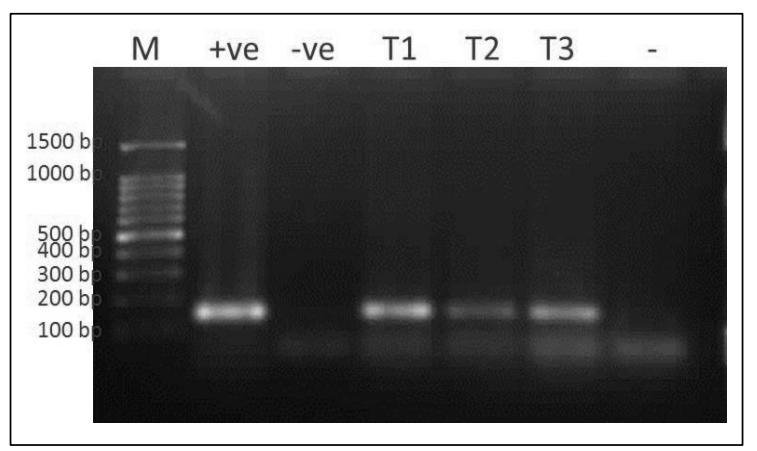

Fig. (4): PCR products obtained using the specific primers of $P$. citrella Co1 (153bp). Lane M: DNA bp size marker; lanes $\mathrm{T} 1, \mathrm{~T} 2$ and $\mathrm{T} 3$ show selection of target prey; lane (-) show the starved spider; lane (+ve) the target insect; lane (-ve) negative control $\left(\mathrm{H}_{2} \mathrm{O}\right)$.

Gut content analysis by using PCR technique for the testing spiders of Cheiracanthium isiacum achieved a positive result for Phyllocnistis citrella DNA that may be important in suppressing this pest population below economic threshold.

\section{ACKNOWLEDGMENTS}

The authors are indebted to Col. Hisham K. El-Hennawy who helped to identify the spider species.

\section{REFERENCES}

Amalin, D.M.; Pena, J.E. and McSorley, R. (2001). Predation by hunting spiders on citrus leafminer Phyllocnistis citrella Stainton (Lepidoptera: Gracillariidae). J. Entomol. Sci. 36 (2): 199-207.

Carroll, D.P. (1980). Biological notes on the spiders of some citrus groves in central and southern California. Entomol. News. 91: 147-154.

Diez, P.A.; Pena, J. E. and Idalgo, P .F. (2006). dynamics of Phyllocnistis citrella (Lepidoptera: Gracillariidae) and its parasitoids in Tafi Viejo,Tucuman, Agentina. Florida Entomologist, Greenstone M.H. and Hunt, J. H. (1993). Determination of prey antigen half-life in Polistes metricus using monoclonal antibody-based immunodot assay. Entomologia Experimentalis et Applicata.

68: 1-7.

Greenstone M. H. and Shufran, K. A. (2003). Spider predation: species-specific identification of gutcontents by polymerase chain reaction. Journal of Arachnology. 31: 131-134.

Stuart, M. K. and Greenstone M.H. (1990). Beyond ELISA: a rapid, sensitive, specific immunodot assay for identification of predator stomach contents. Annals of the Entomological Society of America. 83, 1101-1107.

Sunderland, K.D. (1988). Quantitative methods for detecting invertebrate predation occurring in the field. Annals of Applied Biology. 112: 201-224.

Symondson, W.O.C. (2002). Molecular identification of prey in predator diets. Molecular Ecology. 11: 627-641.

Wheeler, A.G. (1973). Studies on the arthropod fauna of alfalfa. spiders (Araneida). Canadian Entomol. 105: 425-432.

Zhang, Z. Q. (1992). The natural enemies of Aphis gossypii (Hom., Aphididae) in China. J. appl. Entomol. 114: 251-262. 